Research article

\title{
High copper content in vineyard soils promotes modifications in photosynthetic parameters and morphological changes in the root system of 'Red Niagara' plantlets
}

\author{
Vítor Gabriel Ambrosini ${ }^{\mathrm{a}, *}$, Daniel José Rosa ${ }^{\mathrm{b}}$, George Wellington Bastos de Melo ${ }^{\mathrm{c}}$, \\ Jovani Zalamena ${ }^{\mathrm{c}, \mathrm{d}}$, Cesar Cella ${ }^{\mathrm{d}}$, Daniela Guimarães Simão ${ }^{\mathrm{e}}$, Leandro Souza da Silva ${ }^{\mathrm{d}}$, \\ Henrique Pessoa dos Santos ${ }^{c}$, Moreno Tosellif ${ }^{\mathrm{f}}$, Tadeu Luis Tiecher ${ }^{g}$, Gustavo Brunetto ${ }^{\mathrm{d}}$

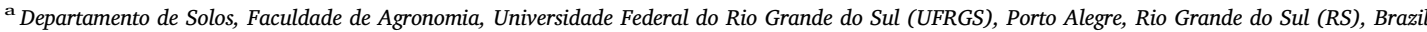 \\ ${ }^{\mathrm{b}}$ Departamento de Fitotecnia, Centro de Ciências Agrárias, Universidade Federal de Santa Catarina (UFSC), Florianópolis, Santa Catarina (SC), Brazil \\ ' Centro Nacional de Pesquisa de Uva e Vinho, Empresa Brasileira de Pesquisa Agropecuária (Embrapa), Bento Gonçalves, RS, Brazil \\ d Departamento de Solos, Centro de Ciências Rurais, Universidade Federal de Santa Maria (UFSM), Santa Maria, RS, Brazil \\ e Departamento de Biologia, Centro de Ciências Naturais e Exatas, UFSM, RS, Brazil \\ ${ }^{\mathrm{f}}$ Dipartimento di Scienze Agrarie, Università di Bologna, Bologna, Italy \\ ${ }^{\mathrm{g}}$ Instituto Federal Farroupilha (IFFar), Campus Alegrete, Alegrete, Brazil
}

\section{A R T I C L E I N F O}

\section{Keywords:}

Available $\mathrm{Cu}$

Net photosynthesis

Maximum quantum yield

Root diameter

Vitis labrusca L

\begin{abstract}
A B S T R A C T
High copper $(\mathrm{Cu})$ soil contents, due to the continuous vineyard application of $\mathrm{Cu}$ fungicides throughout the years, may impair the growth of the shoot and modify the structure of the root system. The current study aimed to investigate the threshold levels of available $\mathrm{Cu}$ in the soil causing toxicity effects in young grapevine plants of 'Red Niagara' cultivated in clay soils. Grapevine plantlets were cultivated in pots containing vineyard devoted soils with increasing contents of available $\mathrm{Cu}\left(25,80,100\right.$ and $\left.165 \mathrm{mg} \mathrm{kg}^{-1}\right)$, for 53 days. Photosynthesis and transpiration rates, and the quantum yield of photosystem II ( Fv/Fm) were evaluated during the cultivation period. At the end of the experiment, the plant nutrient and leaf chlorophyll were determined, along with the anatomical analysis of the root system structure and plant dry matter determination. Higher levels of available $\mathrm{Cu}$ in the soil increased the apoplastic, symplastic and total fraction of the metal in the roots, reducing the other nutrients, especially in the shoots. Photosynthesis, transpiration rates and Fv/Fm were also reduced. Higher levels of $\mathrm{Cu}$ led to anatomical changes in the roots, that increased diameter, number of layers in the cortex, vascular cylinder and total root areas. It also resulted in reduced dry matter production by grapevines.
\end{abstract}

\section{Introduction}

Copper $(\mathrm{Cu})$ accumulation has been reported in vineyard soils (Brunetto et al., 2014; Couto et al., 2015) due to the frequent use of fungicides containing the heavy-metal to control fungal leaf diseases in grapevine (Kabata-Pendias, 2011; Marschner, 2012). Copper is essential to plant growth and development, as part of several organic compounds, such as enzymes and other proteins essential to metabolism, and also it is involved in several physiological processes, such as photosynthesis, respiration and carbohydrate partitioning (Kabata-Pendias, 2011; Marschner, 2012). However, excessive contents of this metal in the soil may cause plant toxicity (Adrees et al., 2015; Kabata-Pendias, 2011).

Copper concentration in vineyard soils is variable depending on the intensity and dosage of the fungicides used, and on the physicochemical properties of the soils (Miotto et al., 2014). In the soil, $\mathrm{Cu}$ is retained by physicochemical bonds of distinct energy levels, thus, their availability in the soil and sorption ability is determined by the contents and type of clay minerals, iron $(\mathrm{Fe})$, aluminum $(\mathrm{Al})$ and manganese $(\mathrm{Mn})$ oxides and hydroxides, carbonates and organic matter, along with $\mathrm{pH}$ and cation exchange capacity (CEC) (Bradl, 2004; McBride, 1994). Adsorption of $\mathrm{Cu}$ added to the soil occurs initially at the most avid adsorption sites, mainly at carboxyl and phenolic groups from organic constituents, which have higher $\mathrm{Cu}$ affinity due to the electronic configuration (Brunetto et al., 2014; Croué et al., 2003). The magnitude of $\mathrm{Cu}$ sorption by the soil is reduced with time when fungicides containing the metal are used due to the saturation of the functional groups at the particles surface, increasing $\mathrm{Cu}$ concentration in the soil solution and its

\footnotetext{
* Corresponding author. Av. Bento Gonçalves, 7712, Bairro Agronomia, 91540-000, Porto Alegre, RS, Brazil.

E-mail address: vgambrosini@gmail.com (V.G. Ambrosini).
} 
availability for roots, leading to a potential plant toxicity risks (Fernández-Calviño et al., 2010; Girotto et al., 2016).

The toxicity induced by $\mathrm{Cu}$ in grapevine may cause several structural modifications in the roots, such as reduction of root elongation, cortex cell plasmolysis (Juang et al., 2012), increased root diameter and alterations in the cell division zone (Ambrosini et al., 2015); along with modifications in nutrient distribution among plant organs (Cambrollé et al., 2015a; Melo et al., 2008; Oliveira et al., 2015; Toselli et al., 2009); and physiological changes, such as oxidative stress (Miotto et al., 2014), reduced concentration of photosynthetic pigments in the leaves (Cambrollé et al., 2013; Oliveira et al., 2015; Tiecher et al., 2017) and modification in gas exchange parameters and chlorophyll fluorescence (Cambrollé et al., 2013, 2015a; Rosa et al., 2014). The effects of $\mathrm{Cu}$ toxicity depend on the amount of the metal available, but also on the soil type, duration of the exposure to $\mathrm{Cu}$, growth conditions and plant genotype (Adrees et al., 2015; Ambrosini et al., 2015; Rosa et al., 2014). Thus, due to complexity of plant response, to better understand the toxic effects of $\mathrm{Cu}$ in vineyard soils, studies should include aspects such as root anatomy and morphology, physiological parameters and nutritional analysis in roots, stems and leaves.

Although the toxic potential of $\mathrm{Cu}$ in young grapevine plants transferred to contaminated soils has been reported (Lai et al., 2010; Tiecher et al., 2017; Toselli et al., 2009), the threshold levels of available $\mathrm{Cu}$ able to effectively cause toxicity effects to 'Red Niagara' (Vitis labrusca) has not been sufficiently determined. Although little used for wine production, 'Red Niagara' is one of the most important grape varieties for grape juice in southern Brazil, and it is widely used for consumption in nature, since it is well adapted to humid climatic conditions. The current study aimed to investigate the effect of different concentrations of available $\mathrm{Cu}$, derived from continuous applications of fungicides throughout the years, on leaf and root physiology, root morphology and nutrient uptake of 'Red Niagara' grapevines, in clay soils with intermediate levels of organic matter.

\section{Material and methods}

\subsection{Soil collection and preparation}

Samples of Typic Hapludalf soil (Soil Survey Staff, 2014) were collected from the 0.0-0.10 m layer in four vineyards located in Bento Gonçalves, in Southern Brazil, Rio Grande do Sul state, exhibiting increasingly levels of available $\mathrm{Cu}\left(25,80,100\right.$ and $\left.165 \mathrm{mg} \mathrm{kg}^{-1}\right)$. The $\mathrm{Cu}$ in the sample soils has accumulated throughout the years, especially due to successive applications of leaf $\mathrm{Cu}$-containing fungicides to control diseases. The soils used in the experiment were chosen because they presented increasing concentrations of available $\mathrm{Cu}$. The other chemical characteristics were the most homogeneous possible. The soils collected in vineyards were already contaminated with $\mathrm{Cu}$ and had been cultivated for 13 to over 80 years (Supplementary material). The time of cultivation and, consequently, addition of $\mathrm{Cu}$ to the soil, significantly alter the dynamics and availability of $\mathrm{Cu}$, because some of the sorption reactions of $\mathrm{Cu}$ to the solid phase are a result of the time factor (AriasEstevez et al., 2007). Thus, when a soil is artificially contaminated and incubated for a short period of time before cultivation, there is a significant change in soil element dynamics and availability and, consequently, plant response to excess $\mathrm{Cu}$. Because of this, we chose to collect contaminated soils in field conditions.

After collection, vineyard soils were air dried, sieved through $2.0 \mathrm{~mm}$ mesh and stored. An aliquot of the soil was submitted to physical and chemical analysis (Table 1). The available $\mathrm{Cu}$ was determined by extraction with Mehlich-1. The remaining soil was equally partitioned to $3.0 \mathrm{~kg}$ and transferred to $3.5 \mathrm{~L}$ pots. The pots did not receive lime and fertilizers, except for nitrogen $(\mathrm{N})$, since the levels of most nutrients were classified in the optimal range, according to the recommendation of CQFS-RS/SC (2016) (Table 1).

\subsection{Plant material}

The plantlets of 'Red Niagara' (Vitis labrusca L.), ungrafted, used in the experiment were obtained from in vitro propagation and gradually acclimated to greenhouse conditions. Plants with four fully expanded leaves were transplanted to pots in September 2013, and supported for vertical growth. Eighty-three days after transplantation, the plants were trimmed at the second bud from the bottom up, and the shoots, discarded. The experiment and evaluations were conducted using newly produced shoots after trimming.

\subsection{Experimental conditions}

The experiment was conducted in a greenhouse with controlled temperature and relative humidity at $25 \pm 2{ }^{\circ} \mathrm{C}$ and $70 \%$, respectively, at Embrapa Uva e Vinho, in Bento Gonçalves, Rio Grande do Sul,

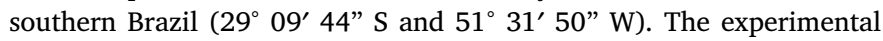
design was randomized blocks with 4 replicates for each one of the four treatments, consisting of vineyard soils with different available $\mathrm{Cu}$ content $\left(25,80,100\right.$ and $\left.165 \mathrm{mg} \mathrm{kg}^{-1}\right)$. We transplanted a young grapevine ('Red Niagara') plantlet per pot with 4 replicates per treatment, with the experimental unit consisting of a pot with a plantlet.

The plants were grown for 53 days after trimming, and the soil in each pot received $15 \mathrm{mg} \mathrm{N} \mathrm{kg}^{-1}$ at 30 and 60 days after transplantation. Soil moisture was monitored daily by weighting and, when necessary, pots were irrigated with distilled water up to $70 \%$ of the field capacity.

\subsection{Physiological analysis}

At 30 and 43 days after trimming (DAT), fluorescence emission of chlorophyll $a$ was measured employing a modulated fluorometer MINIPAM (Walz, Germany). Initial fluorescence (Fo), maximum fluorescence (Fm) and the quantum yield of photosystem II (Fv/Fm) were recorded, using metal pliers (DLC-8) coupled to the sensor, placed at median adaxial region of the leaves away from the veins. Prior to measuring each leaf, the pliers were closed for at least $30 \mathrm{~min}$ to assure that all reaction centers in the analyzed leaf region were open, as instructed by Maxwell and Johnson (2000). Readings were performed from 10 a.m. to 3 p.m., using the fourth fully expanded leaf from each plant.

At 43 DAT, gas exchange measures were carried out using an infrared gas analyzer (LI-6400, LI-COR, Lincoln, USA), set at $500 \mu \mathrm{mol} \mathrm{s}^{-1}$ of air flow and photosynthetically active radiation (PAR) at $800 \mu \mathrm{mol}$ photons $\mathrm{m}^{-2} \mathrm{~s}^{-1}$ (camera 6400-02B, using LED as light source). Physiological parameters such as net photosynthesis (presented as $\mu \mathrm{mol} \mathrm{CO}_{2} \mathrm{~m}^{-2} \mathrm{~s}^{-1}$ ), stomatal conductance (mol m $\mathrm{m}^{-2} \mathrm{~s}^{-1}$ ), transpiration $\left(\mathrm{mol} \mathrm{m}^{-2} \mathrm{~s}^{-1}\right)$ and internal $\mathrm{CO}_{2}$ concentration $\left(\mathrm{mol} \mathrm{m}^{-2} \mathrm{~s}^{-1}\right.$ ) were analyzed. The readings were carried out from 10 a.m. to 3 p.m., using the fourth fully expanded leaf from each plant, and registered when the system coefficient of variation was lower than $1 \%$. On the same day, discs were collected from four leaves at the mid-section of the plant. The leaf samples were weighed, immediately frozen in liquid $\mathrm{N}_{2}$, and stored at $-80^{\circ} \mathrm{C}$ until used. Contents of chlorophyll $a$ and $b$ were determined in the samples employing the Arnon Method, as described by Passos (1996). The four sampled leaf discs from each replicate were pooled during $\mathrm{N}_{2}$ grinding, and extracted to uniformity using $80 \%$ acetone, in the presence of $\mathrm{CaCO}_{3}$, under dim light. The extracts were rapidly filtered through qualitative filter paper and the flow-through was collected in $15 \mathrm{~mL}$ Falcon tubes. After filtering, the volume was completed with the extraction solution and the absorbance was determined spectrophotometrically at 645 and $663 \mathrm{~nm}$ in order to determine the chlorophyll $b$ and $a$ contents, respectively.

\subsection{Sampling of the plant material}

At the end of the experiment, the plants were cut at the soil surface level. The roots were manually removed, washed with water, followed 
Table 1

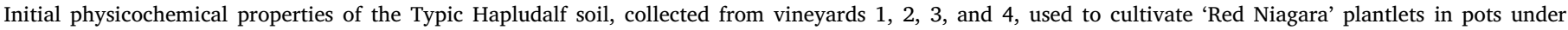
greenhouse conditions.

\begin{tabular}{|c|c|c|c|c|c|}
\hline Attribute & Vineyard 1 & Vineyard 2 & Vineyard 3 & Vineyard 4 & Interpretation (CQFS/RS-SC, 2016) \\
\hline $\mathrm{Cu}$ available $\left(\mathrm{mg} \mathrm{kg}^{-1}\right)$, extracted according to Mehlich-1 ${ }^{(1)}$ & 25 & 80 & 100 & 165 & High $(1,2,3$ and 4$)$ \\
\hline Clay $\left(\mathrm{g} \mathrm{kg}^{-1}\right)$, determined by the densitometer method ${ }^{(2)}$ & 46 & 45 & 49 & 45 & Class 2 \\
\hline $\mathrm{pH}$ in water ${ }^{(3)}$ & 6.1 & 6.2 & 6.1 & 6.4 & High $(1,2,3$ and 4$)$ \\
\hline Organic matter $\left(\mathrm{g} \mathrm{kg}^{-1}\right)$, Walkley-Black Method ${ }^{(1)}$ & 36.3 & 35.7 & 35.2 & 36.2 & Intermediate $(1,2,3$ and 4$)$ \\
\hline $\mathrm{P}$ available (mg dm${ }^{-3}$ ), extracted according to Mehlich-1 (1) & 112 & 156 & 275 & 210 & Very high $(1,2,3$ and 4$)$ \\
\hline $\mathrm{K}$ exchangable $\left(\mathrm{mg} \mathrm{dm}^{-3}\right)$, extracted according to Mehlich-1 & 407 & 237 & 357 & 175 & High (2 and 4$)$; Very high (1 and 3 ) \\
\hline Ca exchangable $\left(\mathrm{cmol}_{\mathrm{c}} \mathrm{dm}^{-3}\right)$, extracted withKCl $1 \mathrm{~mol} \mathrm{~L}^{-1(1)}$ & 12.4 & 11.8 & 11.2 & 11.4 & High $(1,2,3$ and 4$)$ \\
\hline $\mathrm{Mg}$ exchangable $\left(\mathrm{cmol}_{\mathrm{c}} \mathrm{dm}^{-3}\right)$, extracted withKCl $1 \mathrm{~mol} \mathrm{~L}^{-1(1)}$ & 3.2 & 4.1 & 3.7 & 3.2 & High $(1,2,3$ and 4$)$ \\
\hline $\mathrm{Al}$ exchangable $\left(\mathrm{cmol}_{\mathrm{c}} \mathrm{dm}^{-3}\right)$, extracted withKCl $1 \mathrm{~mol} \mathrm{~L}^{-1(1)}$ & 0.12 & 0.07 & 0.02 & 0.06 & Not available \\
\hline $\mathrm{Zn}$ available (mg dm${ }^{-3}$ ), extracted according to Mehlich-1 (1) & 20.5 & 23.7 & 33.9 & 36.0 & High $(1,2,3$ and 4$)$ \\
\hline $\mathrm{CTC}_{\text {eftective }}\left(\mathrm{cmol}_{\mathrm{c}} \mathrm{dm}^{-3}\right)^{(3)}$ & 16.8 & 16.6 & 15.8 & 15.1 & Not available \\
\hline $\mathrm{CTC}_{\mathrm{pH} 7.0}\left(\mathrm{cmol}_{\mathrm{c}} \mathrm{dm}^{-3}\right)^{(4)}$ & 21.1 & 20.8 & 20.7 & 18.5 & High $(1,2,3$ and 4$)$ \\
\hline Base saturation (\%) & 79 & 79 & 76 & 81 & Intermediate (1, 2 and 3); High (4) \\
\hline Aluminum saturation (\%) ${ }^{(6)}$ & 0.6 & 0.3 & 0.1 & 0.3 & Very low $(1,2,3$ and 4$)$ \\
\hline
\end{tabular}

(1) Tedesco et al. (1995); ${ }^{(2)}$ Embrapa (1997); ${ }^{(3)}$ Calculated by: $\mathrm{CTC}_{\text {effective }}=\mathrm{Ca}+\mathrm{Mg}+\mathrm{K}+\mathrm{Na}+\mathrm{Al}$ (CQFS-RS/SC, 2016); ${ }^{(4)}$ Calculated by: CTC ${ }_{\mathrm{pH}}$ $7.0=\mathrm{Ca}+\mathrm{Mg}+\mathrm{K}+\mathrm{Na}+(\mathrm{H}+\mathrm{Al})(\mathrm{CQFS}-\mathrm{RS} / \mathrm{SC}, 2016) ;{ }^{(5)}$ Calculated by: $\mathrm{V}=(\mathrm{Ca}+\mathrm{Mg}+\mathrm{K}+\mathrm{Na}) \times 100 / \mathrm{CTC}_{\mathrm{pH}} 7.0$ (CQFS-RS/SC, 2016); ${ }^{(6)} \mathrm{Calculated} \mathrm{by:}$ $\mathrm{m}=\mathrm{Al} \times 100 /$ CTC $_{\text {effective }}$ (CQFS-RS/SC, 2016).

by subsequent washes with $\mathrm{HCl} 0.01 \mathrm{M}$ and distilled water. The root system and the leaves and stem were dried in an oven with forced air circulation at $65^{\circ} \mathrm{C}$ until constant mass to determine dry matter (DM) production, by precision weighing. Dry plant tissue was ground and stored for posterior analysis of nutrient contents in the roots, stems and leaves. After washing and prior to drying, young roots were separated for analysis of apoplast and symplast $\mathrm{Cu}$ contents. Young roots were identified visually by their lighter color.

\subsection{Nutrient analysis in plant samples}

Total contents of $\mathrm{N}, \mathrm{P}, \mathrm{K}, \mathrm{Ca}$ and $\mathrm{Mg}$ were determined by water extraction using concentrated $\mathrm{H}_{2} \mathrm{SO}_{4}+\mathrm{H}_{2} \mathrm{O}_{2}$ (Tedesco et al., 1995). To determine the contents of $\mathrm{Cu}, \mathrm{Zn}$ and $\mathrm{Fe}$, samples were calcinated in a furnace at $500-550^{\circ} \mathrm{C}$ for $4 \mathrm{~h}$, with subsequent dilution of the ashes in $\mathrm{H}_{2} \mathrm{SO}_{4}$ 0.09 M (Embrapa, 1997). Nitrogen (N) contents were determined according to the semi-micro Kjeldahl Method; K contents, by atomic absorption spectroscopy (Digimed DM-62, Brazil); P contents, by colorimetry (Evolution 60, USA); and the contents of $\mathrm{Ca}, \mathrm{Mg}, \mathrm{Cu}, \mathrm{Fe}$ and $\mathrm{Zn}$ by atomic absorption spectroscopy (AAS, VarianSpectr AA240FS, Australia) (Tedesco et al., 1995).

Extraction of $\mathrm{Cu}$ to determine apoplast and symplast contents was performed as described in Chaignon and Hinsinger (2003). Thus, sequential $\mathrm{Cu}$ extraction was carried out using $\mathrm{HCl} 0.001 \mathrm{~mol} \mathrm{~L}^{-1}$ and $\mathrm{HCl} 1 \mathrm{~mol} \mathrm{~L}^{-1}$ for $0.8 \mathrm{~g}$ root samples previously washed with distilled water. Subsequently, the extract was filtered and stored, and the roots, oven-dried at $65^{\circ} \mathrm{C}$, weighed, finely ground, and submitted to nitroperchloric digestion (Embrapa, 1997). Apoplast (the fraction extracted with $\mathrm{HCl}$ solution) and symplast (the fraction obtained by extract digestion) $\mathrm{Cu}$ concentrations were determined by atomic absorption spectroscopy (AAS, Varian Spectr AA240FS, Australia) (Tedesco et al., 1995).

\subsection{Root anatomical analysis}

Five randomly selected roots per pot were sampled, and sectioned at $0.5-1.0 \mathrm{~cm}$ from the root tip. The roots were sectioned in this apical portion of the root (up to $1.0 \mathrm{~cm}$ ) because this species already presents the typical root development regions: division, elongation and maturation zones. In the selected portion $(0.5-1.0 \mathrm{~cm})$, the cells are differentiated (maturation zone), thus allowing the visualization of possible anatomical changes caused by excess metals, which typically starts in the division zone. The samples were fixed in $2.5 \%$ paraformaldehyde solution in sodium phosphate buffer at $0.1 \mathrm{M}(1: 1), \mathrm{pH} 7.2$, for $24 \mathrm{~h}$ (Schmidt et al., 2009). After fixing, the samples were washed three times with phosphate buffer at $0.1 \mathrm{M}$, and subsequently, dehydrated by ethanolic series. The remaining soil was removed from the fixed samples by ultrasound washing (MaxiClean 750, Unique ${ }^{\circ}$ ) and the samples, infiltrated with glycol-metacrylate (Historesin, Leica ${ }^{\circ}$ ), as instructed by the manufacturer. Transversal sections of $5 \mu \mathrm{m}$ were obtained employing a manual microtome (model RM 2135, Leica ${ }^{\circ}$ ), equipped with steel blades. The sections were stained with toluidine blue at $0.05 \%$ in $0.1 \mathrm{M}, \mathrm{pH} 6.8$ phosphate buffer (O'Brien et al., 1964) and mounted with Canada balsam. The samples were analyzed by light microscopy (model BX40, Olympus ${ }^{\circ}$. Images were digitally captured using a DP71 camera (Olympus ${ }^{\circ}$ ) attached to the microscope.

Root area and diameter, cortex and vascular cylinder total areas were determined by transversal section analysis using Image $J^{\circledR}$ software. The number of cortex layers and cells containing phenolic compounds were determined by counting, using the transversal section images. The cells containing phenolic compounds stain green or bluish green, developed by the use of toluidine blue (O'Brien et al., 1964).

\subsection{Statistical analysis}

Data were initially submitted to the Shapiro-Wilk normality and Bartlett variance homogeneity tests, and, subsequently, to Analysis of Variance (ANOVA). Means were adjusted for significant p-values ( $\mathrm{p}<0.05$ ) using polynomial regression equations to determine the response of the variables to $\mathrm{Cu}$ contents in the soil. Polynomial regressions were considered significant for $\mathrm{p}<0.10$, as shown in Figs. 1-6. The statistical model used for ANOVA was $\gamma_{\mathrm{ij}}=\mu+\beta_{\mathrm{j}}+\tau_{\mathrm{i}}+\varepsilon_{\mathrm{ij}}$; where: $\gamma_{\mathrm{ij}}$ is the response variable, $\mu$ is the general mean, $\beta_{\mathrm{j}}$ is the effect of the blocks, $\tau_{\mathrm{i}}$ is the treatment effect, and $\varepsilon_{\mathrm{ij}}$ is the effect of random errors.

\section{Results}

\subsection{Plant growth}

Young grapevine plants reduced dry matter production as the soil available $\mathrm{Cu}$ increased (Fig. 1). According to the adjusted regression equations, the root system was the plant organ most affected by high $\mathrm{Cu}$ soil concentrations. This is because dry weight was reduced by approximately $40 \%$ with soil available $\mathrm{Cu}$ of $165 \mathrm{mg} \mathrm{kg}^{-1}$ (Fig. 1c). The effect was also observed in leaves and stems, with a reduction in dry matter production of 21 and $19 \%$, with the highest soil available $\mathrm{Cu}$ in comparison to the lowest level of $\mathrm{Cu}$, respectively (Fig. 1a and b). 

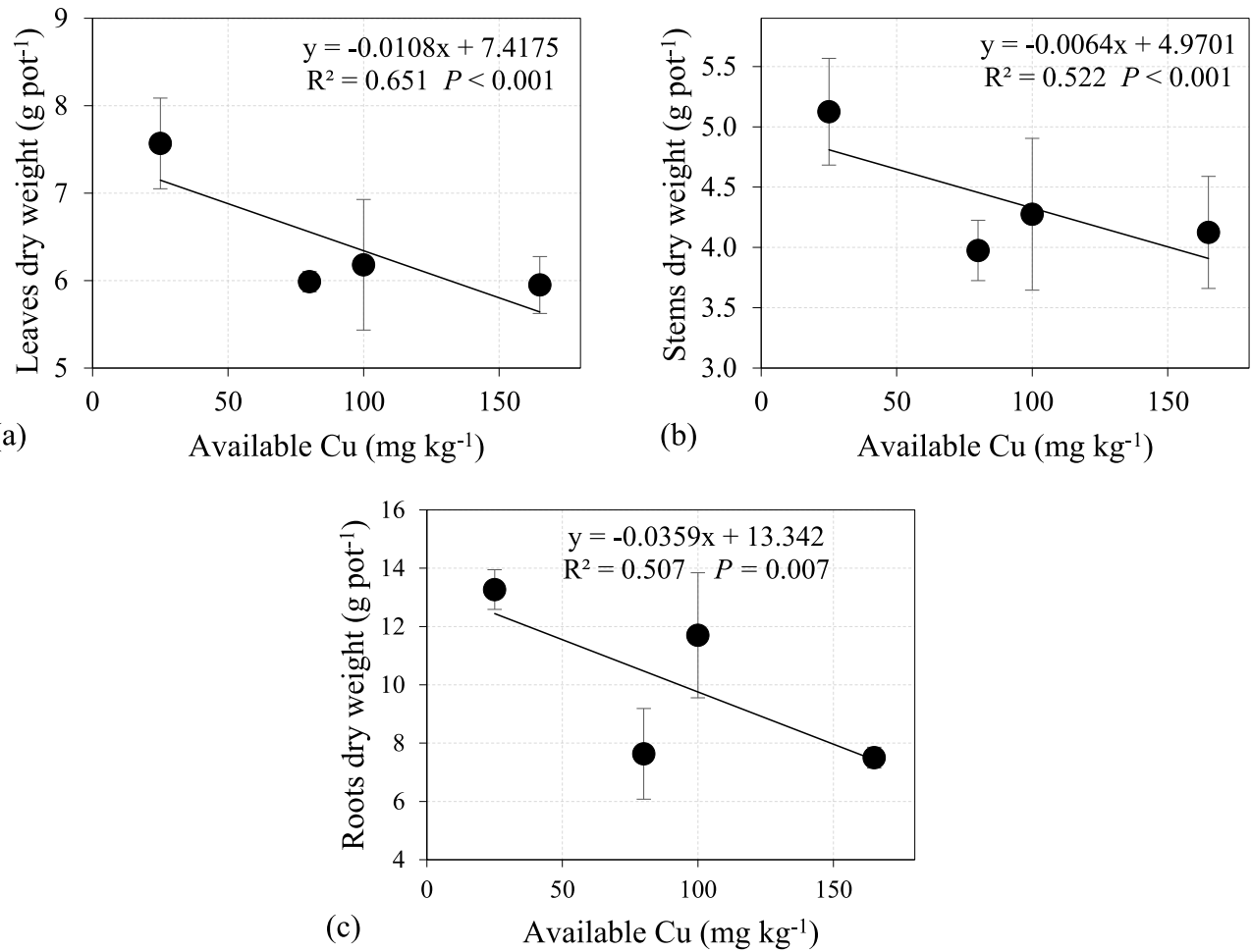

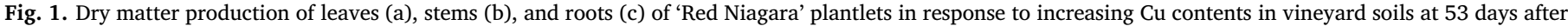
trimming. Mean and standard deviation presented in each bar refer to the four replicates per treatment $(n=4)$.

\subsection{Root apoplastic and symplastic Cu concentrations}

The total concentrations of $\mathrm{Cu}$ in the roots as well as the apoplastic and symplastic fractions increased with the levels of available $\mathrm{Cu}$ in the soil (Fig. 2). Symplastic Cu was higher than the apoplastic fraction in all treatments (Fig. 2a and b). However, the ratio apoplast $\mathrm{Cu} /($ apoplast + symplast $\mathrm{Cu}$ ), which represent the proportion of total $\mathrm{Cu}$ in apoplast, increased linearly from 34 to $47 \%$ as the soil concentrations of
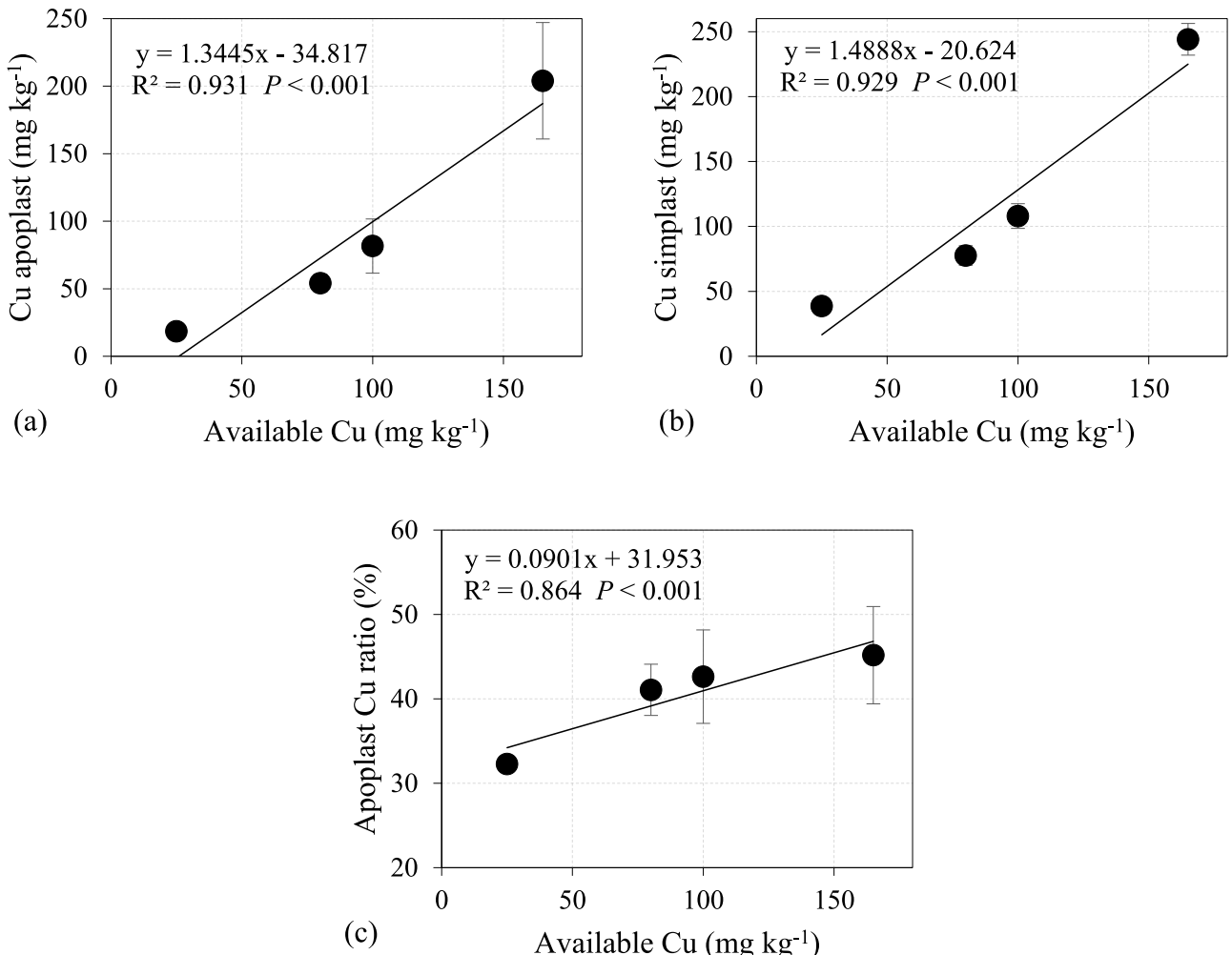

Fig. 2. $\mathrm{Cu}$ content in the apoplast (a) and symplast (b), and apoplast $\mathrm{Cu}$ ratio (c) in roots of 'Red Niagara' plantlets in response to increasing Cu contents in vineyard soils at 53 days after trimming. Mean and standard deviation presented in each bar refer to the four replicates per treatment $(n=4)$. 

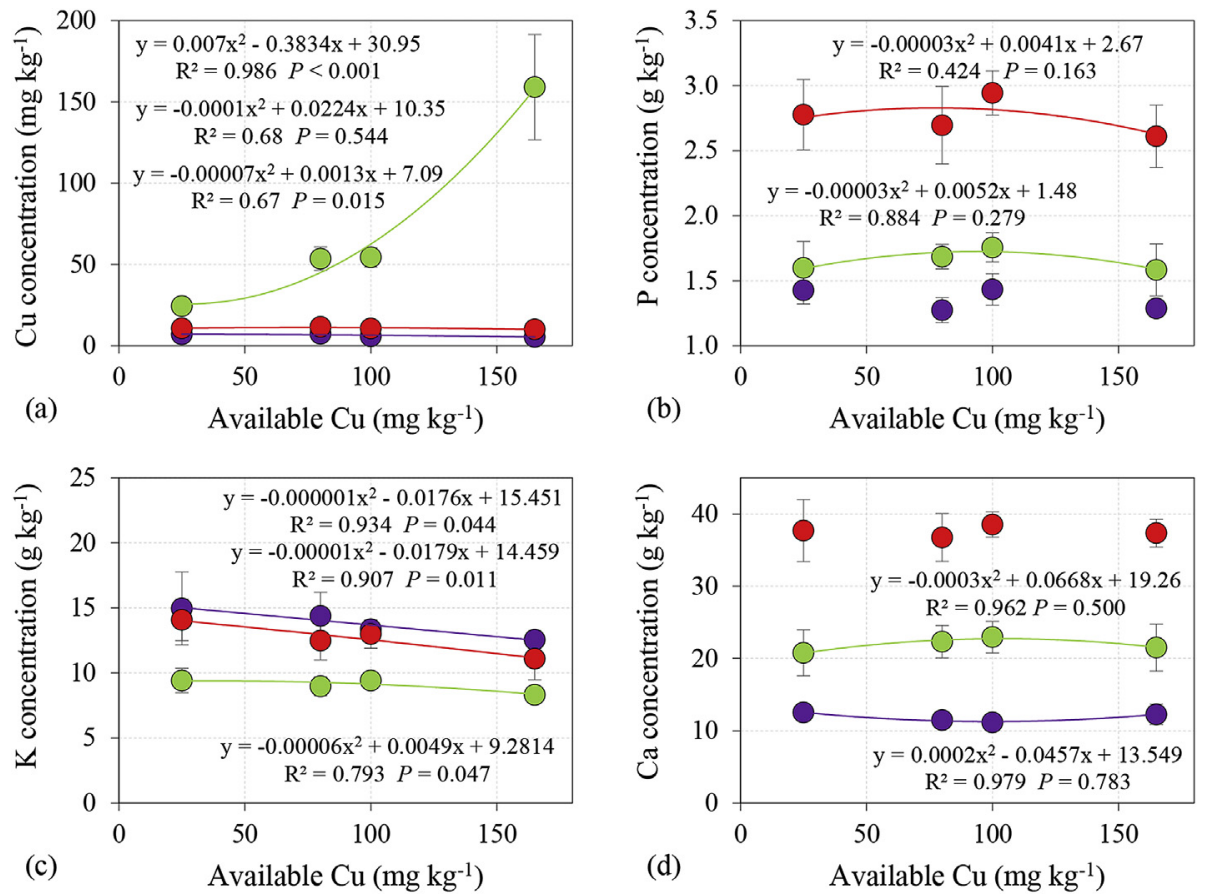

(c) Available $\mathrm{Cu}\left(\mathrm{mg} \mathrm{kg}^{-1}\right)$
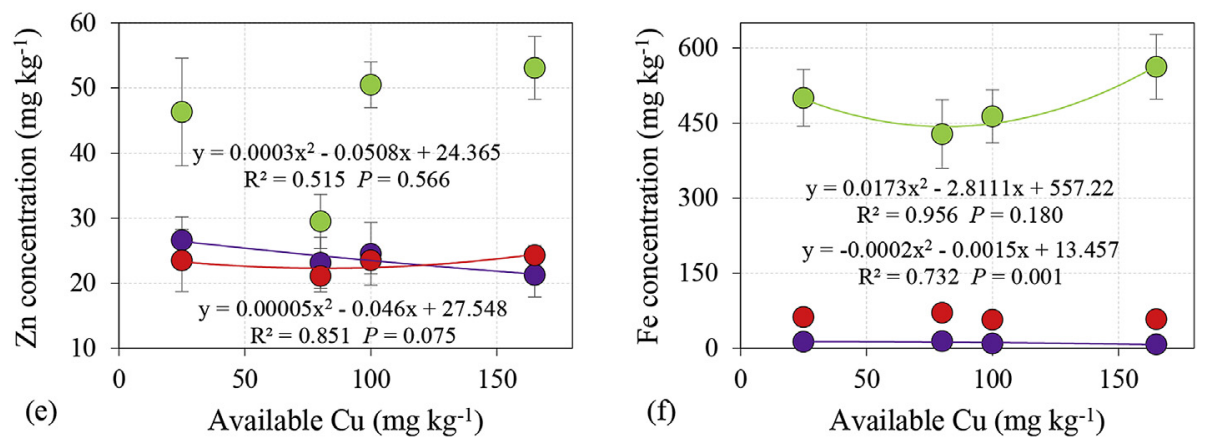

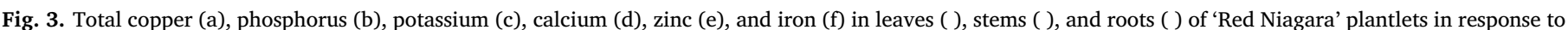

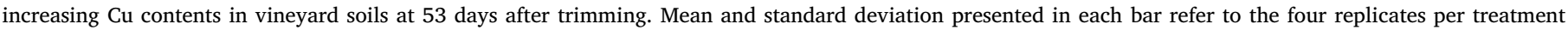
$(n=4)$. (For interpretation of the references to color in this figure legend, the reader is referred to the Web version of this article.)

available $\mathrm{Cu}$ enhanced from 25 to $165 \mathrm{mg} \mathrm{kg}^{-1}$ (Fig. 2c). Therefore, as total $\mathrm{Cu}$ in roots increases, most $\mathrm{Cu}$ is accumulates in apoplast and less in symplast (in proportion).

\subsection{Nutrient concentrations in roots, stems and leaves}

When the levels of available $\mathrm{Cu}$ in the soil increased from 25 to $165 \mathrm{mg} \mathrm{kg}^{-1}$, root total $\mathrm{Cu}$ showed a six-fold increase, while $\mathrm{K}$ had a 10\% decrease (Fig. 3a, c). For the leaves and stems, increasing soil available $\mathrm{Cu}$ affected the levels of all investigated nutrients, except for $\mathrm{N}$ and $\mathrm{Mg}$ (Fig. 3). Leaf and stem total $\mathrm{Cu}$ concentrations were reduced by 7 and $23 \%$ when the levels of $\mathrm{Cu}$ in the soil increased from 25 to $165 \mathrm{mg} \mathrm{kg}^{-1}$, respectively. Whereas, the concentrations of $\mathrm{P}, \mathrm{K}$, and $\mathrm{Fe}$ in leaves and stems decreased by 6,22 and 7 and 10, 17 and 43, respectively (Fig. 3b, c, f).

\subsection{Anatomical structure of the roots}

The increase of soil available $\mathrm{Cu}$ from 25 to $165 \mathrm{mg} \mathrm{kg}^{-1}$ promoted an increase in the root diameter (19\%), total root area (45\%), cortex area $(43 \%)$, vascular cylinder area $(71 \%)$, and number of cortex layers (31\%) (Fig. 4). The number of cells containing phenolic compounds was not affected by soil $\mathrm{Cu}$ (Fig. 4f).

\subsection{Leaf gas exchange, photosynthetic pigments and chlorophyll fluorescence}

According to the adjusted regression equation, net photosynthesis rates, stomatal conductance, internal $\mathrm{CO}_{2}$ concentration and respiration rates increased with soil available $\mathrm{Cu}$ up to $91 \mathrm{mg} \mathrm{kg}^{-1}$ (Fig. 5a, b, c, d). Above this threshold, the investigated parameters decreased down to values similar to those obtained with $25 \mathrm{mg} \mathrm{Cu} \mathrm{kg}^{-1}$. Leaf chlorophyll $a$ and $b$ decreased by 32 and $44 \%$ with an increase of soil $\mathrm{Cu}$ from 25 to $165 \mathrm{mg} \mathrm{kg}^{-1}$ (Fig. $5 \mathrm{e}, \mathrm{f}$ ).

Fluorescence readings of chlorophyll $a$, carried out 30 days after trimming, demonstrated an increase of initial (Fo) and maximum (Fm) fluorescence of 32 and $20 \%$, respectively, when soil available $\mathrm{Cu}$ increased from 25 to $165 \mathrm{mg} \mathrm{kg}^{-1}$ (Fig. $6 \mathrm{a}$, b). At the same time the values of maximum photosystem II quantum yield ( $\mathrm{Fv} / \mathrm{Fm})$ decreased by $9 \%$ (Fig. 6c). At 43 days after trimming, data on Fo, Fm and Fv/Fm were not adjustable to the tested regression models.

\section{Discussion}

Symplast $\mathrm{Cu}$ concentration was higher than the apoplastic fraction for all treatments, although the proportion of $\mathrm{Cu}$ in the apoplast (in comparison to the apoplastic + symplastic $\mathrm{Cu}$ ) increased linearly, showing no stabilization trend, as the available $\mathrm{Cu}$ in the soil increased. 

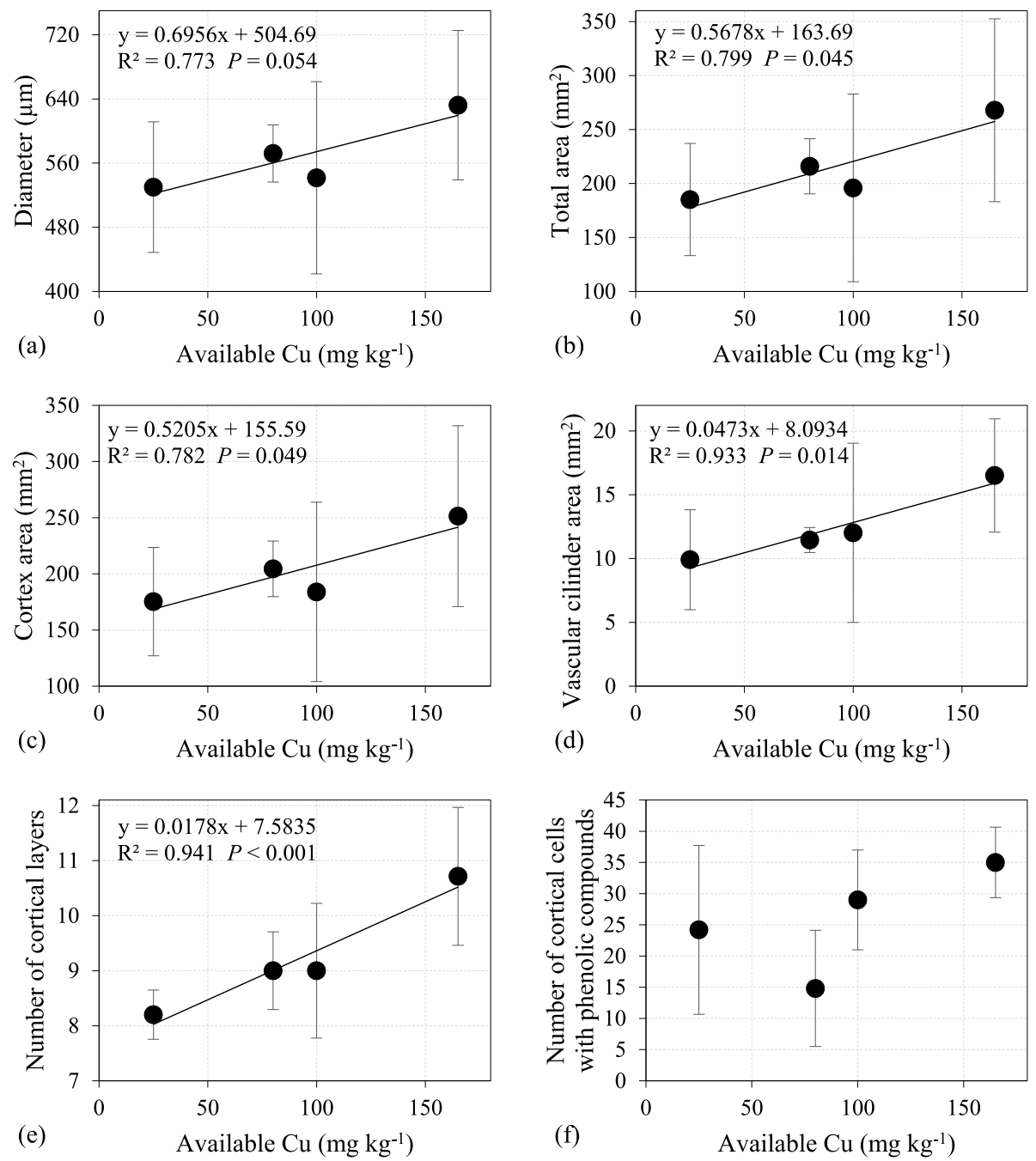

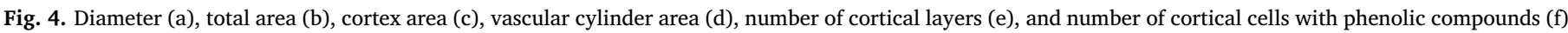

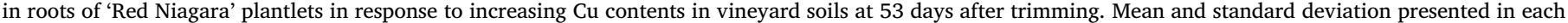
bar refer to the four replicates per treatment $(n=4)$.

The increase of the incidence of apoplastic $\mathrm{Cu}$ was probably due to the metal affinity for hard ligands present in the root cell walls (Kopittke et al., 2014). The observations agree with the ultrastructural analysis of Freitas et al. (2015) showing Cu accumulation in parenchyma cell walls of the xylem, and in the vacuoles of roots exposed to $0.47 \mathrm{mM} \mathrm{Cu}$.

The increase of apoplastic $\mathrm{Cu}$ fraction in roots of plants cultivated in soils with high $\mathrm{Cu}$ concentrations may be an important defense mechanism of the plant cells, since accumulation of $\mathrm{Cu}$ in apoplast reduces its translocation to the shoots (Yruela, 2009). The decrease of $\mathrm{Cu}$ concentrations in the shoots of the plant found in our study corroborate the results of Ambrosini et al. (2015), who reported a higher accumulation of $\mathrm{Cu}$ in the roots than in the shoots of young grapevines exposed to high concentrations of $\mathrm{Cu}$ in the soil, in comparison to plants grown in soils with low levels of the heavy metal. The decrease in $\mathrm{Cu}$ transportation to the shoots is important due to the toxic effects of excess concentrations of the metal in the leaves, which may cause severe ultrastructural damages (Freitas et al., 2015).

In this study, we observed a decrease of the concentrations of $\mathrm{P}$, in roots and leaves, and of $\mathrm{K}$ in the roots, stems and leaves, due to the increasing levels of $\mathrm{Cu}$ in the soil, which indicates that excess $\mathrm{Cu}$ in the soil impairs the nutrient uptake. The lower nutrients uptake is a typical symptom of $\mathrm{Cu}$ toxicity in plants, since the membrane permeability and function of transporters are negatively affected (Cambrollé et al., 2015a; Kabata-Pendias, 2011). The magnitude of the nutritional imbalance depends on plant species, $\mathrm{Cu}$ concentration in the rizhosphere, exposure period, growth conditions (Adrees et al., 2015), etc.

The decrease of the concentrations of $\mathrm{P}$ in plant leaves and roots may be associated to the formation of insoluble metal-phosphate complex in the roots. The formation of the complex was reported in previous studies demonstrating the effect of phosphate in reducing $\mathrm{Cu}$ transport from the roots to the shoots (Guimarães et al., 2016); thus, the complex immobilizes $\mathrm{Cu}$ and $\mathrm{P}$, reducing their transport to the shoots (Guimarães et al., 2016). Another possible explanation for the reduced levels of $\mathrm{P}$ in the leaves, and of $\mathrm{K}$ in the whole plant is the fact that excess $\mathrm{Cu}$ alters membrane permeability, promoting the leakage of $\mathrm{PO}_{4}{ }^{-}$and $\mathrm{K}^{+}$by the roots (Kabata-Pendias, 2011).

In young grapevines, some studies reported the decrease of absorption, accumulation, and contents of essential nutrients promoted by excess Cu. For example, Melo et al. (2008), in a study with young plants of the rootstock 'Paulsen 1103', observed reduced accumulation of $\mathrm{N}$ and $\mathrm{P}$ in the roots, stems and leaves, and of $\mathrm{K}$ in the stems, although increased $\mathrm{K}$ concentrations were found in plant roots and leaves. In contrast, Toselli et al. (2009) observed that high soil Cu concentration decreased $\mathrm{P}, \mathrm{Ca}, \mathrm{Mg}$ and $\mathrm{Fe}$ in the leaves of young 'Sangiovese' plants. In a study with young 'Red Niagara' grapevines, the same cultivar used in this study, Oliveira et al. (2015) found a decrease of N, P, K, Ca and $\mathrm{Mg}$ concentration in plant tissues.

As observed in plants cultivated with the addition of $150 \mathrm{mg} \mathrm{k}^{-1}$ of 

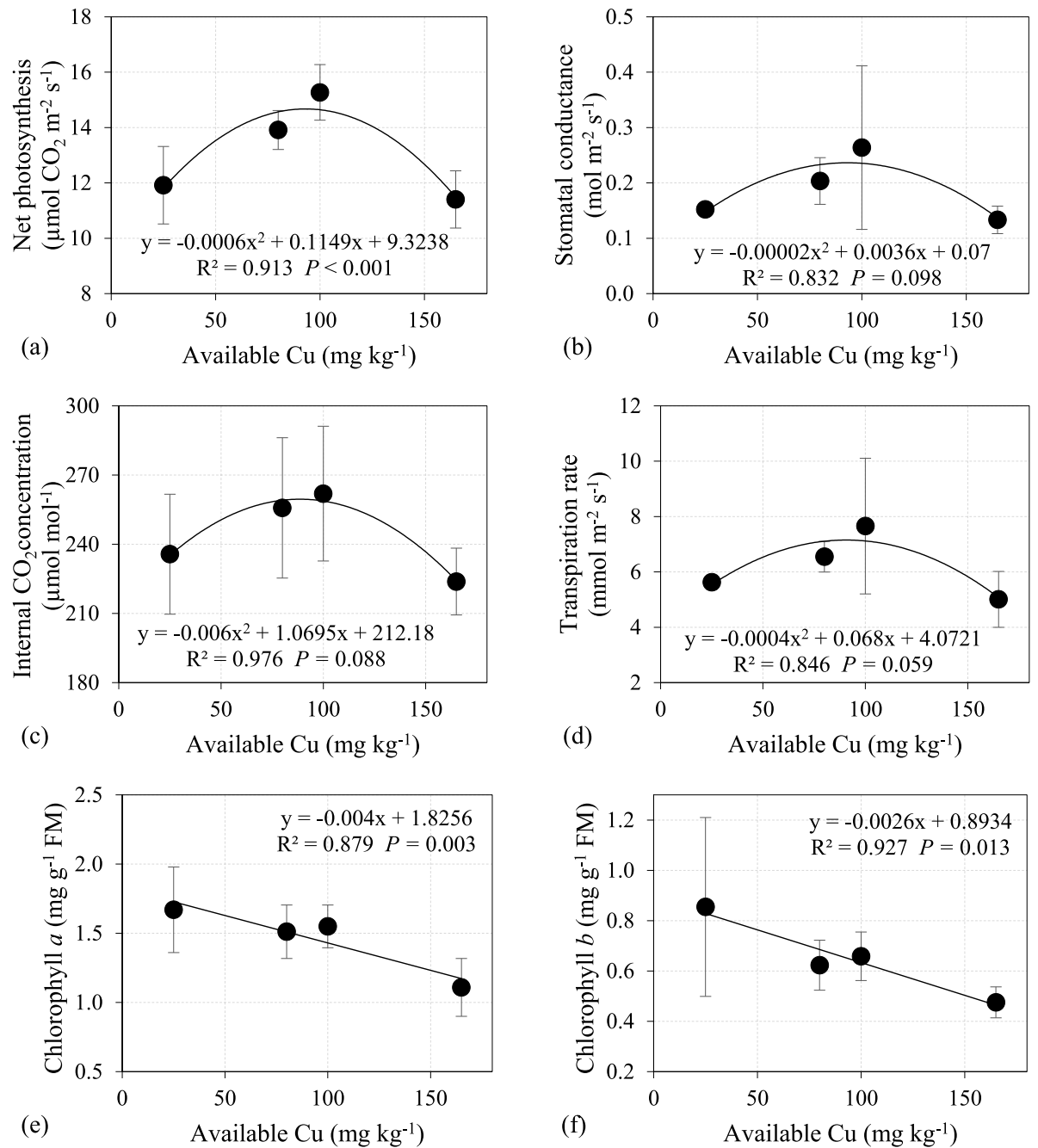

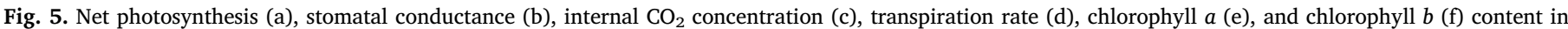

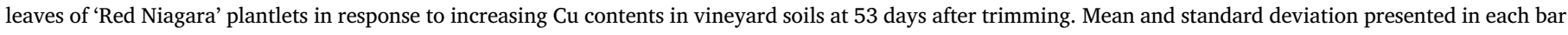
refer to the four replicates per treatment $(n=4)$.

copper, the toxicity caused by heavy metals may promote stomatal closing and stomatal conductance reduction (Paula et al., 2015) and lower density and smaller size of these structures, besides structural differences in the adaxial and abaxial sides (Sagardoy et al., 2010). Such process leads to transpiration reduction, and it decreases water loss for the atmosphere in plants subjected to the application of high metal doses to the soil, due to stomatal conductance decrease (Paula et al., 2015). Accordingly, the transport of nutrient dissolved in the solution used to the root absorption zone reduced, thus it decreased nutrient absorption by the root system (Mott and Franks, 2001), because transpiration is responsible for the nutrient transport dynamics of the soil solution absorbed by the root.

Excessive $\mathrm{Cu}$ also causes a series of direct symptoms like less root dry matter production, changes in the organ anatomy (Ambrosini et al., 2015; Freitas et al., 2015) and root elongation impairment (Juang et al., 2012; Michaud et al., 2008). Direct effects may be observed also in shoots when $\mathrm{Cu}$ concentration is greater than $15 \mathrm{mg} \mathrm{kg}^{1}$ of DM (Adrees et al., 2015), which was not detected in this study (Fig. 3a). Therefore, the reduction on stems and leaves dry matter production must have been caused by reprogram plant metabolism as consequence from less water (Claeys and Inzé, 2013) and nutrients (Ambrosini et al., 2015; Cambrollé et al., 2015a, 2015b; Rosa et al., 2014) uptake as result of alteration in the root anatomy.

The analysis of root transversal sections in this study allowed us to demonstrate an increase in the root diameter, mainly due to the increase in the cortex area. These changes may constitute a direct response of the plant to excess $\mathrm{Cu}$ in the vascular cylinder. The increase of the root diameter occurs because of a disorganization of the cell layers, originated at the root apex, in the meristematic region. As this division region is responsible for forming the rest of the root, a cascade effect occurs, altering the entire structure of the other root regions (elongation, maturation and division). This typically results in thickening and lower root growth, which may contribute to a lower absorption and higher retention of $\mathrm{Cu}$ in the roots, and, therefore, impair its transport to the shoots, where it may cause severe damages, as observed by Ambrosini et al. (2015) in young 'White Niagara' grapevines exposed to $50 \mathrm{mg} \mathrm{Cu} \mathrm{kg}{ }^{-1}$ in sandy soils.

Unlike the results of Ambrosini et al. (2015), we did not find any increase in the number of root cells with phenolic compounds in our study. According to Michalak (2006), the accumulation of these compounds in plants with heavy metal stress is a defense strategy against oxidative stress caused by reactive oxygen species (ROS), which present more intense production in such situations. Thus, in this study, the nonincrease in number of root cells containing phenolic compounds may be response to a possible low production of ROS by plants or because the plants used other mechanisms against ROS produced.

Moreover, the anatomical changes may be caused by the disposition of cell layers, mainly in the cortex, where the concentric organization 

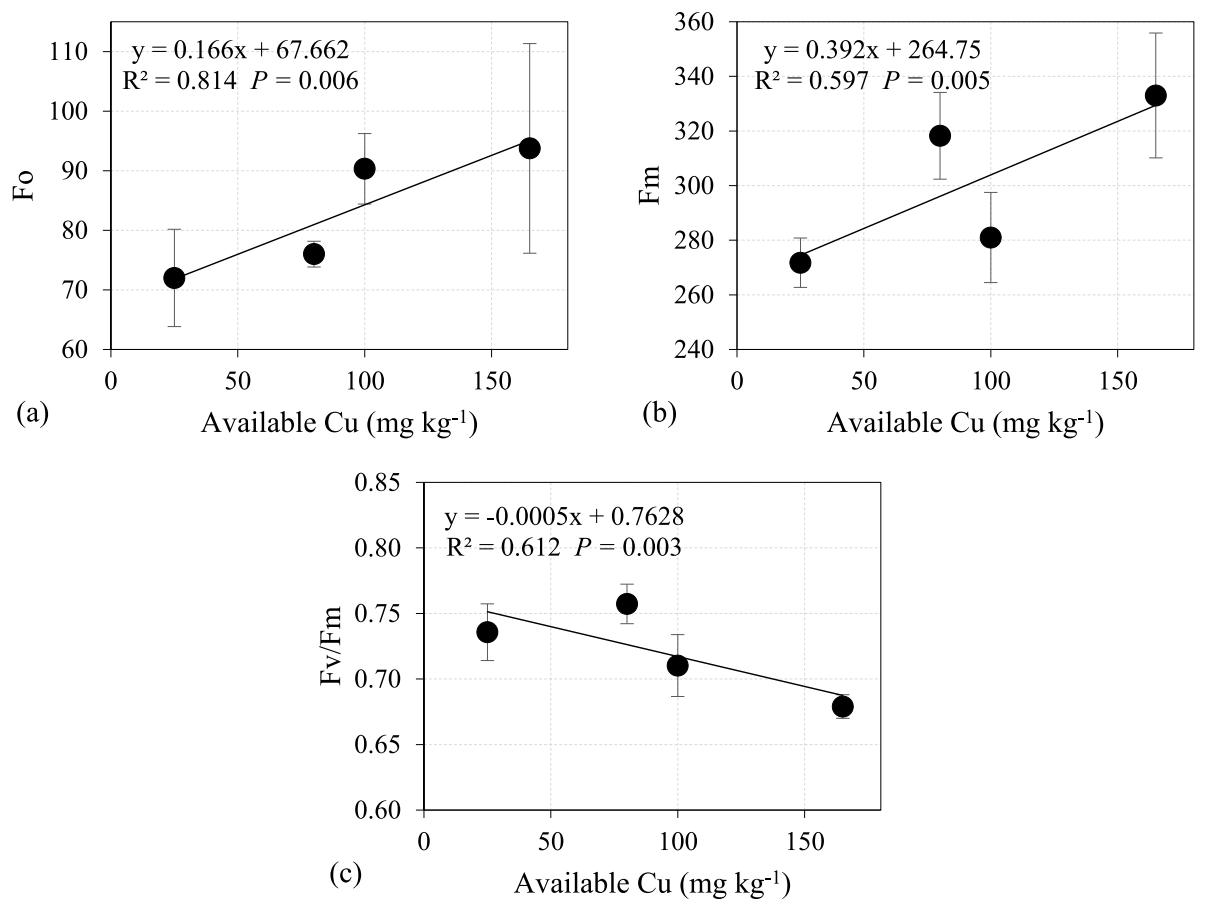

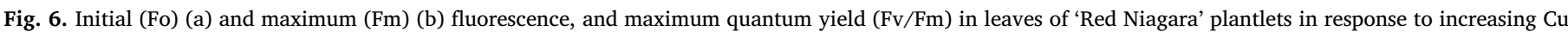
contents in vineyard soils at 30 days after trimming. Mean and standard deviation presented in each bar refer to the four replicates per treatment $(n=4)$.

was impaired as seen in roots subjected to low levels of $\mathrm{Cu}$ (Ambrosini et al., 2015). This occurs because excess $\mathrm{Cu}$ interferes mainly in the region of cell division, promoting changes throughout the rest of the root axis. In the region of cell division, $\mathrm{Cu}$ interacts with hard ligands, compounds with low polarity and high electronegativity present in plant tissues (Kopittke et al., 2014), promoting changes in the cells constituent of the hood, as well as in the cells which will form the rest of the root axis. Thus, in this region of the root, we believe that the increase in diameter is caused by a high vacuolization of the cells that can lead to plasmolysis and cell death (Juang et al., 2012), as well as to the disposition of the cell layers that are not organized concentrically, such as those in roots that grow in the absence of this metal (Ambrosini et al., 2015; Guimarães et al., 2016).

The modifications observed in grapevine roots in the current study consisted in a subset of symptoms, known as Stress-Induced Morphogenic Responses (SIMRs), occurring under moderate-chronic stress, inducing alterations in the plant growth patterns as an escape strategy to avoid the stressing agent (Potters et al., 2007, 2009). Among the SIMRs, processes such as inhibition of cell elongation, stimulation of localized cell division, and complex alterations at cell differentiation level, occur in a coordinated manner and result in plant morphological changes (Potters et al., 2007, 2009), like the increased diameter of the roots observed in the current study.

The increase in liquid photosynthesis was probably due to the high stomatal conductance, internal $\mathrm{CO}_{2}$ concentration and respiratory intensity found in soil $\mathrm{Cu}$ rates up to $100 \mathrm{mg} \mathrm{Cu} \mathrm{kg}^{-1}$ (Cambrollé et al., 2013). It is possible to observe a stability of results for the chlorophyll content and in $\mathrm{Fv} / \mathrm{Fm}$ up to the dose $100 \mathrm{mg} \mathrm{kg}^{-1}$ indicating that up to this concentration of copper, there was no damage in the photosynthetic apparatus. In addition, Fig. 1 shows a greater reduction in the proportion of shoot mass over root mass up to $100 \mathrm{mg} \mathrm{kg}^{-1}$, which favored a hydric adjustment, and this may induce the plant to present a greater stomatal opening, photosynthetic rate.

Vines cultivated with up to $100 \mathrm{mg} \mathrm{Cu} \mathrm{kg}{ }^{-1}$ were not damaged in photosynthesis and this may be due to the fact that this genotype directs a large portion of copper to the root apoplast, restricting the transport of this metal to the leaves and maintaining levels below the range of toxicity in leaves (15-30 $\mathrm{mg} \mathrm{kg}^{-1}$ ) (Kabata-Pendias, 2011). However, the growth data highlights a more sensitive response in the cellular expansion of tissues at the doses tested, even before changes in liquid photosynthesis occur. Only at the highest dose $\left(150 \mathrm{mg} \mathrm{Cu} \mathrm{kg}^{-1}\right)$ did we find a joint effect of copper toxicity preventing cell expansion plus the restriction of photoassimilates causing plant growth restriction.

The highest $\mathrm{Cu}$ external contents induced considerable effects on net photosynthesis, stomatal conductance and intercellular $\mathrm{CO}_{2}$ concentration, suggesting that the decrease of net photosynthesis can be attributed to the different effects of $\mathrm{Cu}$ on the integrity or function of the photochemical apparatus, as well as to their impact on leaf chlorophyll concentrations (Cambrollé et al., 2015a). The decrease of stomatal conductance may be related to an alteration in the K:Ca ratio in the guard cells (Cambrollé et al., 2013), since the concentration of $\mathrm{K}$ in the leaves was reduced with increasing concentrations of available $\mathrm{Cu}$ in the soil. Besides that, reduction on net photosynthesis above $100 \mathrm{mg}$ $\mathrm{Cu} \mathrm{kg}^{-1}$ in soil may be associated to the less root biomass production in this treatment, which limits water uptake. Under limited water uptake, plants have diminished Calvin cycle activity, which results in less energy production and in reduction in net photosynthesis (Claeys and Inzé, 2013).

In general, $\mathrm{Cu}$ accumulation is higher in the roots, especially under exposure to high concentrations of the heavy metal, resulting, as seen in our study, in lower concentration of $\mathrm{Cu}$ in the shoots (stems and leaves), where it remained inferior to $15-30 \mathrm{mg} \mathrm{kg}^{-1} \mathrm{DM}$, levels able to induce slight toxicity (Adrees et al., 2015). Thus, the concentration of $\mathrm{Cu}$ in the leaves were not sufficient to modify chlorophyll biosynthesis and electron transport, to the point of compromising the efficiency of the photosynthetic apparatus, not affecting leaf processes, as normally observed in $\mathrm{Cu}$ stressed plants (Freitas et al., 2015).

Since $\mathrm{Cu}$ concentration in the stems and leaves was below the toxicity levels of $15-30 \mathrm{mg} \mathrm{kg}^{-1} \mathrm{DM}$ (Adrees et al., 2015), the reduction in gas exchange induced by the higher soil $\mathrm{Cu}$ availability is probably associated to less water uptake by roots as consequence to decrease of root development by the toxic effect of $\mathrm{Cu}$. Plants under water deficit needs to balance water uptake and loss to aim avoid several drought stress, and the main mechanism for this is limit water evaporation and 
gas exchange by closing stomata, besides restrict shoot growth (Claeys and Inzé, 2013). Therefore, response to limited water uptake may also explain the less dry matter production by plants under $\mathrm{Cu}$ stress.

The observed reduction in photosynthetic rates and PSII quantum yield (Fv/Fm), and the increase in initial (Fo) and maximum (Fm) fluorescence in response to increased levels of $\mathrm{Cu}$ available in the soil may be associated to the reduction in chlorophyll contents, which induces deficiencies in the photosynthetic apparatus and increased the photoinhibition of PSII (Cambrollé et al., 2015a). In turn, the less chlorophyll contents should be a consequence of the decrease in the levels of $\mathrm{Fe}$ and $\mathrm{P}$ in shoots, that also reduced in response to increasing levels of $\mathrm{Cu}$ (Ambrosini et al., 2017).

In a study evaluating the tolerance of wild vines to calcareous soils, Cambrollé et al. (2015b) observed a decrease of N, P, S, K and Cu in the leaves in response to increasing $\mathrm{CaCO}_{3}$ concentrations in the soil. This response also reduced photosynthetic activity, as proven by a reduction in the values of $\mathrm{Fv} / \mathrm{Fm}$ along with a decrease in chlorophyll contents, which corroborates the results of the current work. On the other hand, regressions were not adjusted for chlorophyll fluorescence variables at 43 days. This is because photoinhibition can be caused by damage to the photosynthetic components, which may be long-term and irreversible (chronic photoinhibition) or, similar to what occurred in our study, short-term and reversible (dynamic photoinhibition) (Werner et al., 2002). This response may have occurred through the adaptation of the plants to the adverse conditions, mainly due to the reduction in photosynthetic pigment contents, which reduces the absorption of light energy and, consequently, the amount of energy that the plant must dissipate, reducing photoinhibition.

\section{Conclusions}

The increase in $\mathrm{Cu}$ availability in the soil reduces nutrient $(\mathrm{P}, \mathrm{K}, \mathrm{Ca}$, $\mathrm{Zn}, \mathrm{Fe}$ ) contents in the plant, impairs the growth of young grapevines, promotes alterations in the anatomical structure of the roots, such as increase of root diameter, affects photosynthesis processes, such as $\mathrm{CO}_{2}$ assimilation rate, stomatal conductance, internal $\mathrm{CO}_{2}$ concentration and respiration rates, and reduces the concentration of photosynthetic pigments in the leaves of 'Red Niagara' plantlets.

\section{Contribution}

Repeated applications of Cu-based fungicides and solutions to control foliar diseases in vines have been causing accumulation of $\mathrm{Cu}$ in vineyard soils around the world, which can lead to physiological and morphological changes in young vines. These modifications may inhibit nutrient absorption and plant growth, damaging the plant development. However, there are few studies involving $\mathrm{Cu}$ effects on anatomy and plant physiology concomitantly. In this context, the current study aimed to investigate the threshold levels of available $\mathrm{Cu}$ in the soil (obtained over the years of grapevine cultivation) causing toxicity effects in young grapevine plants of 'Red Niagara' cultivated in clay soils. Excess $\mathrm{Cu}$ in soil increases the content of this metal e reduces the other nutrient contents in the plant, especially in the shoots. Photosynthesis, transpiration rates and Fv/Fm were also reduced. Higher levels of $\mathrm{Cu}$ led to anatomical changes in the roots, that increased diameter, number of layers in the cortex, vascular cylinder and total root areas. It also resulted in reduced dry matter production by grapevines. Concentration of available $\mathrm{Cu}$ in the soil, as high as $100 \mathrm{mg} \mathrm{Cu} \mathrm{kg}^{-1}$, causes toxicity in 'Red Niagara' plantlets and delays the establishment of vine young plants in the field. The results of this manuscript may be applied to the field production and are relevant to the advancement of research with copper toxicity in vines.

\section{Appendix A. Supplementary data}

Supplementary data related to this article can be found at http://dx. doi.org/10.1016/j.plaphy.2018.05.011.

\section{References}

Adrees, M., Ali, S., Rizwan, M., Ibrahim, M., Abbas, F., Farid, M., Zia-ur-Rehman, M., Irshad, M.K., Bharwana, S.A., 2015. The effect of excess copper on growth and physiology of important food crops: a review. Environ. Sci. Pollut. Res. 22, 8148-8162.

Ambrosini, V.G., Rosa, D.J., Prado, J.P.C., Borghezan, M., Melo, G.W.B., Soares, C.R.F.S., Comin, J.J., Simão, D.G., Brunetto, G., 2015. Reduction of copper phytotoxicity by liming: a study of the root anatomy of young vines (Vitis labrusca L.). Plant Physiol. Biochem. 96, 270-280.

Ambrosini, V.G., Rosa, D.J., Basso, A., Borghezan, M., Pescador, R., Miotto, A., Melo, G.W.B., Soares, C.R.F.S., Comin, J.J., Brunetto, G., 2017. Liming as an ameliorator of copper toxicity in black oat (Avena strigosa Schreb.). J. Plant Nutr. 40, 404-416.

Arias-Estevez, M., Novoa-Munoz, J.C., Pateiro, M., Lopez Periago, E., 2007. Influence of aging on copper fractionation in an acid soil. Soil Sci. 172, 225-232.

Bradl, H.B., 2004. Adsorption of heavy metal ions on soils and soils constituents. Colloid Interface Sci. 277, 1-18.

Brunetto, G., Miotto, A., Ceretta, C.A., Schmitt, D.E., Heinzen, J., Moraes, M.P., Canton, L., Tiecher, T.L., Comin, J.J., Girotto, E., 2014. Mobility of copper and zinc fractions in fungicide amended vineyard sandy soils. Arch. Agron Soil Sci. 60, 609-624.

Cambrollé, J., García, J.L., Ocete, R., Figueroa, M.E., Cantos, M., 2013. Growth and photosynthetic responses to copper in wild grapevine. Chemosphere 93, 294-301.

Cambrollé, J., García, J.L., Figueroa, M.E., Cantos, M., 2015a. Evaluating wild grapevine tolerance to copper toxicity. Chemosphere 120, 171-178.

Cambrollé, J., Garcia, J.L., Ocete, R., Figueroa, M.E., Cantos, M., 2015b. Evaluating tolerance to calcareous soils in Vitis vinifera ssp. sylvestris. Plant Soil 396, 97-107.

Chaignon, V., Hinsinger, P., 2003. A biotest for evaluating copper bioavailability to plants in a contaminated soil. J. Environ. Qual. 32, 824-833.

Claeys, H., Inzé, D., 2013. The agony of choice: how plants balance growth and survival under water-limiting conditions. Plant Physiol. 162, 1768-1779.

Croué, J.P., Benedetti, M.F., Violleau, D., Leenheer, J.A., 2003. Characterization and copper binding of humic and nonhumic organic matter isolated from the South Platte River: evidence for the presence of nitrogenous binding site. Environ. Sci. Technol. 37, 328-336.

Couto, R.R., Benedet, L., Comin, J.J., Belli Filho, P., Martins, S.R., Gatiboni, L.C., Radetski, M., Valois, C.M., Ambrosini, V.G., Brunetto, G., 2015. Accumulation of copper and zinc fractions in vineyard soil in the mid-western region of Santa Catarina, Brazil. Environ. Earth Sci. 73, 6379-6386.

CQFS-RS/SC (Comissão de Química e Fertilidade do Solo - RS/SC), 2016. Manual de calagem e adubação para os Estados do Rio Grande do Sul e de Santa Catarina, 11.ed. SBCS - Núcleo Regional Sul/UFRGS, Porto Alegre.

Embrapa, 1997. Manual de métodos de análise de solo. Embrapa-CPNS, Rio de Janeiro.

Fernández-Calviño, D., Soler-Rovira, P., Polo, A., Arias-Estévez, M., Plaza, C., 2010. Influence of humified organic matter on copper behavior in acid polluted soils. Environ. Pollut. 158, 3634-3641.

Freitas, T.A., França, M.G.C., Almeida, A.F., Oliveira, S.J.R., Jesus, R.M., Souza, V.L., Silva, J.V.S., Mangabeira, P.A., 2015. Morphology, ultrastructure and mineral uptake is affected by copper toxicity in young plants of Inga subnuda subs. luschnathiana (Benth.) T.D. Penn. Environ. Sci. Pollut. Res. 22, 15479-15494.

Girotto, E., Ceretta, C.A., Rossatto, L.V., Farias, J.G., Brunetto, G., Miotto, A., Tiecher, T.L., De Conti, L., Lourenzi, C.R., Schmatz, R., Giachini, A., Nicoloso, F.T., 2016. Biochemical changes in black oat (Avena strigosa Schreb) cultivated in vineyard soils contaminated with copper. Plant Physiol. Biochem. 103, 199-207.

Guimarães, P.R., Ambrosini, V.G., Miotto, A., Ceretta, C.A., Simão, D.G., Brunetto, G., 2016. Black oat (Avena strigosa Schreb.) growth and root anatomical changes in sandy soil with different copper and phosphorus concentrations. Water, Air, Soil Pollut. $227,1-10$.

Juang, K.W., Lee, Y.I., Lai, H.Y., Wang, C.H., Chen, B.C., 2012. Copper accumulation, translocation, and toxic effects in grapevine cuttings. Environ. Sci. Pollut. Res. 19, 1315-1322.

Kabata-Pendias, A., 2011. Trace Elements in Soils and Plants, 4 ed. CRC Press, Boca Raton.

Kopittke, P., Menzies, N.W., Wang, P., McKenna, B.A., Wehr, J.B., Lombi, E., Kinraide, T.B., Blamey, F.P.C., 2014. The rhizotoxicity of metal cations is related to their strength of binding to hard ligands. Environ. Toxicol. Chem. 33, 268-277.

Lai, H.Y., Juang, K.W., Chen, B.C., 2010. Copper concentrations in grapevines and vineyard soils in central Taiwan. Soil Sci. Plant Nutr. 56, 601-606.

Marschner, P., 2012. Marschner's Mineral Nutrition of Higher Plants, 3 ed. Academic Press, London.

Maxwell, K., Johnson, G.N., 2000. Chlorophyll fluorescence - a practical guide. J. Exp. Bot. 51, 659-668.

McBride, M.B., 1994. Environmental Chemistry of Soils. Oxford University Press, New York.

Melo, G.W., Brunetto, G., Schafer Junior, A., Kaminski, J., Furlanetto, V., 2008. Matéria seca e acumulação de nutrientes em videiras jovens cultivadas em solos com diferentes níveis de cobre. Ver. Bras. Agrociênc 14, 72-76.

Michalak, A., 2006. Phenolic compounds and their antioxidant activity in plants growing under heavy metal stress. Pol. J. Environ. Stud. 15, 523-530.

Michaud, A.M., Chappellaz, C., Hinsinger, P., 2008. Copper phytotoxicity affects root elongation and iron nutrition in durum wheat (Triticum turgidum durum L.). Plant Soil $310,151-165$.

Miotto, A., Ceretta, C.A., Brunetto, G., Nicoloso, F.T., Girotto, E., Farias, J.G., Tiecher, T.L., De Conti, L., Trentin, G., 2014. Copper uptake, accumulation and physiological changes in adult grapevines in response to excess copper in soil. Plant Soil 374, 593-610. 
Mott, K.A., Franks, P.J., 2001. The role of epidermal turgor in stomatal interactions following a local perturbation in humidity. Plant Cell Environ. 24, 657-662.

O'Brien, T.P., Feder, N., McCully, M.E., 1964. Polychromatic staining of plant cell walls by toluidine blue O. Protoplasma 59, 368-373.

Oliveira, P.D., Ambrosini, V.G., Melo, G.W.B., Zalamena, J., Brunetto, G., 2015. Uso de calcário na amenização da toxidez de cobre em videiras jovens. Cientifica 43, 427-435.

Passos, L.P., 1996. Métodos analíticos e laboratoriais em fisiologia vegetal. Embrapa, Coronel Pacheco.

Paula, L.S., Silva, B.C., Pinho, W.C.S., Barbosa, M.A.M., Guedes-Lobato, E.M.S., Segura, F.R., Batista, B.L., Júnior, F.B., Lobato, A.K.S., 2015. Silicon (Si) ameliorates the gas exchange and reduces negative impacts on photosynthetic pigments in maize plants under Zinc (Zn) toxicity. Aust. J. Crop. Sci. 9, 901-908.

Potters, G., Pasternak, T.P., Guisez, Y., Palme, K.J., Jansen, M.A.K., 2007. Stress-induced morphogenic responses: growing out of trouble? Trends Plant Sci. 12, 98-105.

Potters, G., Pasternak, T.P., Guisez, Y., Jansen, M.A.K., 2009. Different stresses, similar morphogenic responses: integrating a plethora of pathways. Plant Cell Environ. 32, 158-169.

Rosa, D.J., Ambrosini, V.G., Basso, A., Borghezan, M., Brunetto, G., Pescador, R., 2014 Photosynthesis and growth of young "Niágara Branca" vines (Vitis labrusca L.) cultivated in soil with high levels of copper and liming. In: BIO Web of Conferences 3, pp. 01005.

Sagardoy, R., Vázquez, S., Florez-Sarasa, I.D., Albacete, A., Ribas-Carbó, M., Flexas, J.,
Abadía, J., Morales, F., 2010. Stomatal and mesophyll conductances to $\mathrm{CO}_{2}$ are the main limitations to photosynthesis in sugar beet (Beta vulgaris) plants grown with excess zinc. New Phytol. 187, 145-158.

Soil Survey Staff, 2014. Keys to Soil Taxonomy, twelfth ed. USDA-SCS, Washington. Schmidt, E.C., Scariot, L.A., Rover, T., Bouzon, Z.L., 2009. Changes in ultrastructure and histochemistry of two red macroalgae strains of Kappaphycus alvarezii (Rhodophyta, Gigartinales), as a consequence of ultraviolet B radiation exposure. Micron 40, 860-869.

Tedesco, M.J., Gianello, C., Bissani, C.A., Bohnen, H., Volkweiss, S.J., 1995. Análises de solo, plantas e outros materiais, 2 ed. UFRGS, Porto Alegre.

Tiecher, T.L., Tiecher, T., Ceretta, C.A., Ferreira, P.A.A., Nicoloso, F.T., Soriani, H.H., De Conti, L., Kulmann, M.S.S., Schneider, R.O., Brunetto, G., 2017. Tolerance and translocation of heavy metals in young grapevine (Vitis vinifera) grown in sandy acidic soil with interaction of high doses of copper and zinc. Sci. Hortic. 222, 203-212.

Toselli, M., Baldi, E., Marcolini, G., Malaguti, D., Quartieri, M., Sorrenti, G., Marangoni, B., 2009. Response of potted grapevines to increasing soil copper concentration. Aust J. Grape Wine Res. 15, 85-92.

Werner, C., Correia, O., Beyschlag, W., 2002. Characteristic patterns of chronic and dynamic photoinhibition of different functional groups in a Mediterranean ecosystem. Funct. Plant Biol. 29, 999-1011.

Yruela, I., 2009. Copper in plants: acquisition, transport and interactions. Funct. Plant Biol. 36, 409-430. 